\title{
VÝCHODOLAŠSKÁ NÁŘEČÍ VERSUS GWARA ZACHODNIOCIESZYŃSKA, CZYLI DIALEKTOLOGICZNA WOJNA O ZAOLZIE
}

Słowa klucze: gwara, język etniczny, czesko-polskie pogranicze językowe, czeska część Śląska Cieszyńskiego, Adolf Kellner, Andrzej Sowa, Karol Dejna, Jaromír Bělič, Arnošt Lamprecht Keywords: dialect, ethnic language, Czech-Polish linguistic borderland, the Czech part of the Cieszyn/ Těšín region, Adolf Kellner, Andrzej Sowa, Karol Dejna, Jaromír Bělič, Arnošt Lamprecht

\section{Wprowadzenie}

Celem niniejszego artykułu jest omówienie problemu, na który zwykle nie zwraca się uwagi w pracach dotyczących (oddzielnie) dialektologii czeskiej lub polskiej, ponieważ wykracza on poza granice jednej i drugiej. Problem ten jest jednak ważny i - jak się okazuje - również niebywale emocjonujący. Przyjmując fakty dialektologiczne prezentowane $\mathrm{w}$ znanych i cenionych opracowaniach naukowych, często nie zauważamy obecności pewnych tematów tabu, miejsc przemilczanych lub niedoprecyzowanych i nawet nie przypuszczamy, jak ogromne znaczenie mają lub miały w konkretnej czasoprzestrzeni. Do refleksji tej skłoniła nas lektura przyczynków do trwającej kilkadziesiąt lat dyskusji o przynależności gwary zachodniocieszyńskiej do polskiego bądź czeskiego areału językowego.

$\mathrm{Na}$ wstępie należy udzielić czytelnikowi podstawowych informacji. Omawiana $\mathrm{w}$ artykule przestrzeń to tereny historycznego Księstwa Cieszyńskiego, które w 1920 r. zostało przyznane po części nowo powstałemu państwu polskiemu, a po części czechosłowackiemu. Po stronie zachodniej (czeskiej) granice dawnego 
księstwa sięgały aż po rzekę Ostrawicę i obejmowały tzw. Śląską (Polską) Ostrawę. To, co przez Polaków nazywane jest Zaolziem, a co zostało na niespełna rok przed wybuchem II wojny światowej włączone do Polski, to nieco węższy obszar przygraniczny czeskiego Śląska Cieszyńskiego, położony bardziej na wschód od wspomnianej rzeki'. Specyfika tego niewielkiego terenu (ok. $\left.800 \mathrm{~km}^{2}\right)$ tkwi w świadomości etnicznej tamtejszych mieszkańców, w ich propolskiej lub proczeskiej orientacji narodowej. Dla językoznawcy istotne jest to, że mowa potoczna ludności mniejszościowej (polskiej) i większościowej (czeskiej) jest tu w znacznym stopniu taka sama - jej podstawę tworzą tradycyjna gwara zachodniocieszyńska oraz naleciałości niemieckie, czeskie, (ogólno)polskie. Polska dialektologia traktuje gwarę zachodniocieszyńską jako polską, natomiast źródła czeskie starają się dowieść jej czeskiego (morawskiego, ewentualnie przejściowego/laskiego) charakteru, a każda $\mathrm{z}$ dialektologii narodowych dostrzega w tej odmianie cechy, które wykazywał bądź wykazuje do dziś jeden lub drugi zachodniosłowiański język etniczny².

Ta odmienna interpretacja afiliacji językowej Zaolzia stała się przyczyną zasygnalizowanego w tytule sporu, którego najważniejsze tezy czerpiemy przede wszystkim z prac Adolfa Kellnera Východolašská nářečí (1946-1949), Jaromíra Běliča Sedm kapitol o češtině (1955) i Nástin české dialektologie (1972) oraz Karola Dejny Polsko-laskie pogranicze językowe na terenie Polski (1951-1953), ale też z opublikowanych reakcji na wspomniane prace, $z$ reakcji na te reakcje itd. Badacze reprezentujący czeskie spojrzenie wychodzą z założeń panujących w ich dialektologii, i to co najmniej od II wojny światowej, czyli z podziału czeskiego języka etnicznego na cztery podstawowe zespoły dialektalne: 1) czeski sensu stricto (czeski właściwy, tzn. obejmujący zachodnie tereny języka czeskiego aż po Wyżynę Czesko-Morawską; w terminologii czeskiej: nářeční skupina česká v užším smyslu), 2) środkowomorawski (nářeční skupina středomoravská), 3) wschodniomorawski (nářeční skupina východomoravská) oraz 4) laski (nářeční skupina slezská, ewentualnie lašská). W czeskiej części Śląska czescy badacze rozróżniają tradycyjnie: 1) dialekt środkowolaski (centralny, ostrawski, střredolašské nářečí), 2) zachodniolaski (opawski, západolašské nářečí) i 3) „morawski”, południowy (występujący w okolicach Štramberka lub Frenštátu, štrambersko-frenštátské nářeč́, moravská podskupina slezských nářečíi). Po II wojnie

1 Należy podkreślić, że pojęcie „Zaolzie” jest znacznie upolitycznione, a rzeka Olza, o którą tu chodzi, nie wyznacza granicy państwowej wzdłuż całego swojego przebiegu, lecz tylko w pewnych jego odcinkach (szczegółowo zob. Bogocz 2016: 227 i n.).

2 Różnicę między gwarami przejściowymi a mieszanymi polscy i czescy dialektologowie formułują w sposób identyczny lub bardzo podobny, czyli mniej więcej tak, jak przedstawiła to Halina Karaś (2014). Fakt ten jednak nie znaczy, że ocena konkretnych narzeczy przez stronę polską i czeską jest pod tym względem taka sama. W dialektologii czeskiej obserwuje się wyraźną tendencję do udowadniania czeskiego charakteru Śląska Cieszyńskiego w Czechosłowacji (Republice Czeskiej), łącznie z używaną tam mową.

3 O dialektach czeskich oraz rozwoju czeskiej tradycji dialektologicznej zob. Bogoczová 2015, 2016. 
światowej czeska dialektologia wprowadziła w obieg za pośrednictwem publikacji A. Kellnera nowy termin - narzecza wschodniolaskie (východolašská nářečí), który można uważać za próbę uzasadnienia językowej (a nie tylko geopolitycznej) przynależności Zaolzia do czeskiego organizmu państwowego ${ }^{4}$.

W teorii Kellnera nářečí východolašská tworzą więc czwarty podzespół dialektów laskich. W tym podzespole dostrzega się (według dialektologów czeskich i polskich) następujące formacje gwarowe: 1) zachodnie pasmo przejściowe, 2) gwarę centralną (w okolicach Cieszyna, Trzyńca, Karwiny), 3) północną (skoncentrowaną w okolicach Bogumina) oraz 4) jabłonkowską. Bardziej dokładny podział wyszczególnia też odcinek nydecki (miejscowość Nydek/Nýdek znajduje się w pobliżu granicznej góry Czantorii) lub sam Jabłonków (w odróżnieniu od okolicznych wiosek).

\section{Stanowisko Adolfa Kellnera}

Streszczenie interesującej nas dyskusji rozpoczynamy od kontrowersyjnej z polskiego punktu widzenia pracy Kellnera Východolašská nářeč́s (1946-1949). Jej autor dobrze orientował się w dotychczasowych badaniach językoznawczych dotyczących gwary zachodniocieszyńskiej, łącznie z tymi, które prowadzili jego polscy koledzy. Omówił je pokrótce w przedmowie do drugiego tomu pracy (1949 II), wymieniając Lucjana Malinowskiego, Jana Bystronia i Kazimierza Nitscha, którego zasługi oceniał szczególnie wysoko. Podał też kilka nazwisk czeskich językoznawców: Alois Vojtěch Šembera, František Bartoš, Jan Loriš i in. Do zbadania gwary zachodniocieszyńskiej Kellner został wybrany w 1937 r. przez członków Komisji Dialektologicznej przy Macierzy Morawskiej, a prawdopodobnie - przez czołowych czeskich językoznawców bohemistów Františka Trávníčka i Bohuslava Havránka, którzy wykonanie prac badawczych zlecili młodszemu koledze rodem z laskiego Štramberka zapewne dlatego, że sami dotychczas nie wyrazili zdania na temat genezy gwar cieszyńskich i przynależności językowej czeskiej części Śląska Cieszyńskiego. Badania Kellnera miały więc wypełnić tę lukę. Przebywając na Zaolziu, Kellner zorientował się stosunkowo szybko nie tylko w tutejszej sytuacji językowej, ale także narodowościowej. Doszedł do wniosku, że używana tu gwara zachodniocieszyńska nie jest nieomylnym wskaźnikiem etniczności jej użytkownika. Na Zaolziu spędził około

4 Inne czeskie terminy odnoszące się do tego obszaru to lansowane nieco później przez Běliča polsko-czeskie pasmo mieszane (nářečí polsko-českého smíšeného pruhu), gwara zachodniocieszyńska (západotěšínské nářečí, np. Arnošt Lamprecht - patrz poniżej) lub gwary śląskopolskie (nářečí slezskopolská, np. Jan Balhar (2002)) - w przeciwieństwie do śląsko-morawskich, czyli laskich.

5 Adolf Kellner (1904-1953), który odbył staż naukowy m.in. u Kazimierza Nitscha, mógł się już wtedy wykazać pewnym dorobkiem badawczym. Gwarom śląskim poświęcił wcześniej artykuły: Slezsko po stránce jazykové (Kellner 1946a) oraz Jazykové poměry v levém horním Poodří (Kellner 1946b). 
dziewięciu miesięcy (1937-1938), po czym zebrany materiał przewiózł do Brna i tam (podczas II wojny światowej) opracowywał. Po wojnie wynik swej pracy przedstawił w dwutomowej monografii. Pierwszy tom (1946 I) zawiera opis systemu gwary wchodniolaskiej, drugi (1949 II) - fragmenty wypowiedzi jej użytkowników, słownik gwarowy, mapkę badanych terenów i wysunięte $z$ badań wnioski.

W jaki sposób Kellner zinterpretował dialekty wschodniolaskie? Przede wszystkim podał w wątpliwość ich genetycznie polski charakter (Kellner 1949 II: 60-61), uważając je za takie, w których występują cechy zarówno polskie, jak i czeskie, tzn. za „typowo przejściowe”, przy czym w ich słownictwie dostrzegał nawet przewage elementów czeskich, względnie śląskomorawsko-słowackich (ibid.: 60). Miał świadomość, że takie ujęcie sprawy jest niezgodne ze stanowiskiem przedwojennych polskich językoznawców (K. Nitscha, Mieczysława Małeckiego, Zdzisława Stiebera), wskazujących - przeciwnie - na cechy polskie występujące w sąsiednich gwarach laskich, które ich zdaniem zostały dopiero wtórnie sczechizowane.

Nie możemy w tym miejscu podać pełnej charakterystyki gwar „wschodniolaskich" dokonanej przez Kellnera, zwracamy więc uwagę na jej najbardziej dyskutowane szczegóły. W głosowni gwary zachodniocieszyńskiej Kellner za czeskie uważa: zmianę $e>y /$ 'i typu chlyb/chlib, jelyń/jeliń; niezmiękczone $s / z$ w pozycji przed miękkimi wargowymi (np. sp'yvać/spjyvać, smich) oraz przed miękkimi $l$ i $n$ (np. slifka, sńih), występujące w zachodnim pasie przejściowym; brak palatalizacji wargowych $\mathrm{w}$ wyrazach typu kamyń, řmmyń; brak przegłosu $e>o \mathrm{w}$ imiesłowach czasu prze-

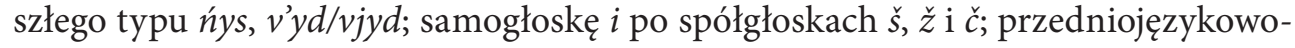
-zębowe $\downarrow$ (zamiast dwuwargowego); frykatywne $\check{r}$; obecność dźwięcznego $h$; przeważającą nieobecność labializacji $o\left({ }^{u} o\right.$ ) lub mazurzenia. We fleksji za czeskie uważa formy kozańi lub głupi (w rodz. n.); formy imiesłowów typu třit, třity; formę zaimka wskazującego ty zamiast te (M. i B. l. mn.) lub wstępujące tu - według Kellnera połączenie $d v^{\prime} e$ piva zamiast dva piva (por. Kellner 1949 II: 62-63) ${ }^{6}$. W odniesieniu do wspomnianego pasma przejściowego, znajdującego się na zachodzie opisywanego terenu, Kellner starał się uzasadnić zanotowaną tu rzekomo wymowę p’ińć, v'unzać, kunsek w ten oto sposób: miejscowa ludność, nieznająca ze swojego języka ojczystego (tzn. laskiej odmiany języka czeskiego lub języka czeskiego - ogólnego) nosówek, stara się je zastąpić (dosłownie: „reprodukować” ich brzmienie), korzystając z rodzimych połączeń samogłoski $+N$, które najbardziej odpowiadają nosowej wymowie (ibid.: 66). Ten asynchroniczny sposób wymowy, wraz ze zmianą $e N$ na ' $i N$, jest - zdaniem autora - świadectwem czeskiego pochodzenia obecnej ludności. Tak wypowiadał się autor, który w innym miejscu swojej pracy podkreślał, iż nie należy utożsamiać mowy mieszkańców $\mathrm{z}$ ich etnicznością. To tylko jedna $\mathrm{z}$ wielu sprzeczności zawartych w monografii Kellnera.

6 Przejściowego charakteru terenów zachodniocieszyńskich starał się Kellner dowieść, przytaczając 18 cech systemowych i 54 jednostki leksykalne (nieonimiczne). 
Użyty w tytule termin východolašská nářečí Kellner usprawiedliwiał tym, że praca miała zostać oddana do druku jeszcze podczas okupacji i że inny jej tytuł mógłby przyciągnąć niepożądaną uwagę ewentualnych cenzorów (Labocha 1997: 114), co nie zostało przez przeciwników Kellnera zaakceptowane. Kellner napisał dosłownie, że chodzi o „čistě dialektologický název”, przeciwstawny wobec terminów západolašský (opawski) i středolašský (ostrawski). Napisał też, że gwary wschodniolaskie nie ograniczają się do terenów po czeskiej stronie granicy państwowej, ale o tym, czy po stronie polskiej są takie same, nie mógł się przekonać z powodu napięcia panującego między oboma państwami. Na mapce zawartej w tomie drugim została wyznaczona granica czesko-wschodniolaska (czyli oddzielająca gwary czeskie od przejściowych, czesko-polskich), która przebiega między miejscowościami Vrbice i Hrušov, Petřvald i Michálkovice, Bartovice i Kunčice itd., z czego wynika, że gwary terenów po południowo-zachodniej stronie linii uważał autor za zdecydowanie czeskie.

Jak już zostało zasygnalizowane, autor Východolašských nářč́i niekonsekwentnie przestrzegał zapowiedzianej zasady odróżniania gwary od deklarowanej przez jej nosicieli etniczności oraz potrzeby odróżniania granicy gwarowej od granicy świadomości narodowej, podkreślając fakt, że tożsamość narodowa to o wiele bardziej złożone zjawisko społeczne, a kwestia językowa to tylko jedna strona tego problemu (Kellner 1946 I: XI, 1949 II: 47).

\section{Pierwsze reakcje Andrzeja Sowy}

Jak wynika z lektury prasy zaolziańskiej, uwagę na pracę Kellnera zwróciły miejscowym Polakom gazeta „Głos Ludu” i miesięcznik Polskiego Związku Kulturalno-Oświatowego „Zwrot”. Artykuły w „Głosie...” (z 22 VI 1950, 25 VI 1950, 13 VII 1950) zostały podpisane skrótem -et-, natomiast autorem tych, które zostały opublikowane w „Zwrocie”, był z całą pewnością Leon Derlich7, publicysta, pisarz, językoznawca amator ${ }^{8}$, a przede wszystkim zagorzały obrońca polskości Zaolzia, występujący tu pod pseudonimem Andrzej Sowa (tego pseudonimu używamy w odniesieniu do

7 Leon Derlich (1905-1964) urodził się i mieszkał przez całe życie w Karwinie na Zaolziu. W wieku 18 lat zachorował na zapalenie chrząstki stawowej, został sparaliżowany i resztę życia spędził przykuty do łóżka, całkowicie zależny od opieki siostry. Paraliż jednak nie pozbawił go jasności umysłu - pomimo choroby i wbrew tragicznemu losowi pogłębiał wiedzę językoznawczą i etnograficzną, by móc prowadzić fachowe polemiki z językoznawcami narodowości polskiej, czeskiej i niemieckiej. Zbierał i analizował materiał językowy z Zaolzia (udzielał rzekomo w tej sprawie konsultacji np. Nitschowi), pisał artykuły do miesięcznika kulturalnego „Zwrot”, a także do pism „Zaranie Śląskie” i „Język Polski”. Jest autorem satyrycznych wierszy i opowiadań (por. Kadłubiec 2005: 187; Upominat się o Zaolzie).

$8 \mathrm{Na}$ brak odpowiedniego wykształcenia językoznawczego Sowy wskazał Kellner w stanowczej obronie własnej interpretacji gwar wschodniolaskich opublikowanej na łamach historyczno-etnograficzno-socjologicznego pisma „Slezský sborník” pod wymownym tytułem Aby bylo jas- 
Derlicha także poniżej, por. Sowa 1950a-c). Sowa był prawdopodobnie najbardziej uważnym czytelnikiem pracy Kellnera i dostrzegał w niej być może także to, co nie zostało dosłownie napisane.

Sowa był oburzony pracą Kellnera, czego nie ukrywał. W 1950 r. w „Zwrocie” ukazały się trzy jego artykuły, oparte, co prawda, na wiarygodnych faktach językowych, lecz równocześnie utrzymane w niezwykle emocjonalnej, wręcz agresywnej i obelżywej retoryce. W pierwszym z nich (1950a: 3-4) autor przedstawił Kellnera jako pseudobadacza operującego z jednej strony „obiektywną prawdą”, z drugiej „nacjonalistyczną bajką”, między którymi „wesoło i swawolnie hasa faktyczna rzeczywistość gwarowa, pomyłki, przemilczenie znanych faktów, półprawdy i bzdurne fałsze" (ibid.: 3). Położył nacisk na to, że Kellner podczas pobytu na Zaolziu gościł w domu frysztackiego ${ }^{9}$ starosty Jaroslava Haeringa (czego zresztą Kellner nie ukrywał), z czego wynika, że badania przebiegały za zgodą i pod ochroną oficjalnych władz miasta, że materiał gromadził Kellner w ścisłej współpracy z napływowym nauczycielstwem czeskim oraz działaczami SMOL ${ }^{10} \mathrm{i}$ że nie poprosił o żadną konsultację nikogo z grona miejscowych nauczycieli szkół polskich lub osób zajmujących się, choćby w sposób nienaukowy, gwarą cieszyńską. Gdyby tak się stało - pisał Sowa być może nie popełniłby aż tak wielu błędów, szczególnie w hasłach słownikowych i transkrypcji tekstów gwarowych, takich jak np. nieujednolicony zapis wymowy samogłoski pośredniej między $o$ i $u$ oraz stosowanie litery $u$ (a nie $u$ ó $)$ w miejscach, gdzie powinno być $u_{\text {; }}$ labilność w zapisie nosówek w miejscach przed spółgłoskami szczelinowymi, gdzie do dziś dominuje wymowa synchroniczna (np. ov'yzi m'y so / ovjy źi mjyso), a nie asynchroniczna ( $y n)$, jak sugeruje Kellner.

Po kilku miesiącach pobytu na Zaolziu Kellner - zdaniem Sowy - „wyewakuował się” do Brna, by „pod fachowym nadzorem zleceniodawców” przeanalizować bogaty materiał językowy. Aluzje te miały na celu podważenie wiarygodności „może z góry uplanowanego celu przedsięwzięcia”, które zdaniem zaolziańskiego publicysty już od samego początku było niefortunne: powierzenie zadania niedoświadczonemu koledze, wpływ osób o wrogim nastawieniu wobec Polaków, zaściankowy charakter środowiska czeskich „doradców” itp. Kellner został pokazany jako przesadnie pokorny wobec autorytetów, poddający się ideologii nacjonalistycznej, jako pseudonaukowiec, który nawet $\mathrm{z}$ własnych badań nie potrafi wyciągnąć odpowiednich wniosków, lecz fałszuje je pod dyktando antypolskiej propagandy.

no... (Kellner 1951b). W kilkustronicowym elaboracie Kellner m.in. odmówił udzielania dalszych wyjaśnień osobom niekompetentnym (w domyśle Sowie).

9 Obecnie Frysztat/Fryštát to historyczne centrum górniczego miasta Karwina.

10 Chodzi o czeski odpowiednik Macierzy Szkolnej Księstwa Cieszyńskiego (pełna nazwa: Slezská Matice osvěty lidové), symbol „czechizacji ludu śląskiego”. Była to organizacja powstała na wzór polskiej Macierzy Szkolnej, a jej celem było m.in. „bronić interesów państwa czechosłowackiego” (Szymeczek 2013: 33). 
Drugi artykuł (Sowa 1950b), napisany w identycznym jak poprzedni duchu, Sowa poświęcił Gołężycom (Holasici), szczepowi słowiańskiemu zamieszkującemu w VIII-IX w. ziemie położone na wschód od Bramy Morawskiej. Jednocześnie podkreślał: „nauka nigdy prawdopodobnie nie orzeknie [...], do której rodziny dialektów, polskiej czy czeskiej, należała jego mowa”, ponieważ „zbyt dawne i mrokami zasłonięte to czasy, a wiadomo także, jak nikle i skąpo różniły się wtedy między sobą oba dzisiejsze języki" ${ }^{\prime \prime}$. Zajmując to stanowisko, Sowa krytycznie odniósł się do skłonności czeskich badaczy (nie wykluczając Kellnera) do nazywania mowy Gołężyców czeskim substratem. Sowa zwrócił uwagę na to, jak nieudolnie Kellner manewruje pomiędzy stanowiskiem o czeskim charakterze pierwotnego żywiołu zamieszkującego opisywane tereny a tezą o istnieniu w tym czasie niewielkich różnic między dialektami zachodniosłowiańskimi.

Kolejne zarzuty Sowy wobec Kellnera dotyczą etymologii nazwy zaolziańskiej miejscowości Błędowice oraz pochopnych wniosków wyciągniętych „z licznych przykładów oddziaływania czeszczyzny na narzecza śląskopolskie”². Artykuł Sowy pełen jest ironicznych docinków (np. „Wysoko uczony dialektolog jak gdyby nie wiedział..."), aluzji oraz niedwuznacznych złośliwości:

Rzeczy nieistotne, półprawdy i pomyłki, umyślne przemilczenia dowodowych faktów i posługiwanie się pseudonaukowym miętniactwem (sic) i matactwem oto „argumenty”, przy pomocy których dokonano w wydanej monografii „obalenia" tez obiektywnej nauki polskiej i czeskiej, stwierdzających pierwotną polskość mowy ziemi Cieszyńskiej. Dlatego też jak dźwięk triumfalnych fanfar na pogrzebie brzmią końcowe słowa monografii: „oblast východolašských dialektů i západní Čadecko náležely od původu $\mathrm{k}$ jazykovému souboru československému... polskost západního Těšínska, postulovaná polskými badateli, nemá prastarých kořenů, nýbrž je výsledkem kolonisačního proudění v poměrně nedávné minulosti” (II, str. 86). Błędne założenie i rachunek nieuczciwy, więc też i wynik fałszywy (ibid.: 10).

W trzeciej krytycznej ocenie monografii Kellnera Sowa (1950c) poświęcił uwagę procesom kolonizacyjnym w historii Śląska Cieszyńskiego. W związku z nimi zarzuca Kellnerowi, że z jednej strony podkreśla rzekomą kolonizację wschodniomorawską (i wpływ języka czeskiego), z drugiej - nie wspomina ani słowem o kolonizacji niemieckiej ${ }^{13}$, która pojawiła się co najmniej w dwu etapach, trwała dłużej i wywarła

11 Podobne stanowisko zarysował czeski badacz głosowni prasłowiańskiej, paleoslawista A. Lamprecht (1967: 42) - patrz poniżej.

12 Tymi przykładami były zdaniem Kellnera wyrazy z głoską $h$. W reakcji na to Sowa zaznaczał, że na Zaolziu istnieje „dość skromny i znaczeniowo ograniczony zasób napływowych wyrazów z czeskim dźwiękiem zawierających krtaniowe h" (hned, hruby, hruza, hrưm, miejscami też hledać), używany tu „obok ogromnej masy wyrazów z typowo polską głoską g” (Sowa 1950b: 9), np.: gańba, głůd, głos, noga, dłůgi, gưrnik, ganić itp.

13 Twierdzenie to nie do końca jest prawdziwe: Kellner (1949 II: 74) pisze o kolonizacji niemieckiej i germanizacji, ale odnośnie do regionu opawskiego. 
o wiele większy wpływ niż kolonizacja czeska. W przypadku XV- i XVI-wiecznych wpływów czeszczyzny na język polski stwierdza - tym razem zgodnie z Kellnerem - że nie zatrzymały się one na rzece Olzie i że czeszczyzna była w tym czasie pożądanym „dialektem kulturalnym, »językiem salonowym « szlachty i mieszczan” (ibid.: 4).

Błędna, zdaniem Sowy, jest też interpretacja Kellnera dotycząca napływu ludności wołoskiej (o ile nie chodziło o „umyślną niewiedzę”). Nic w tym dziwnego, gdyż czeski dialektolog odwołał się do „humorystycznej” pracy archiwariusza Václava Davídka Osídlení Těšínska Valachy (1940). W tym miejscu należy podkreślić, że Sowa nie kwestionuje „wołoskiej” (bałkańskiej, rumuńskiej) etniczności tego żywiołu napływowego, tak jak uczynił to M. Małecki, który już w 1938 r. zakładał, że kolonizacja ta wprawdzie została prawdopodobnie zainicjowana na Bałkanach, ale sam wołoski żywioł nie dotarł aż na tereny zachodniosłowiańskie, tylko wepchnął tu inny element słowiański (np. słowacki, rusiński) ${ }^{14}$.

Jeszcze większą różnicę zdań między Sową a Kellnerem dostrzegamy w sprawie imigracji taniej siły roboczej z austriackiej Galicji, którą Kellner nazywa polską kolonizacją i której przypisuje o wiele większy wpływ niż ten, jaki wywarła w rzeczywistości. Zdaniem Sowy język osadników z Galicji nie pozostawił prawie żadnego śladu w sytuacji językowej w Cieszyńskiem, gdzie pozycja języka polskiego była już w tym czasie dostatecznie stabilna:

[...] po prostu sprawdza się na tym przykładzie dobrze znane zjawisko w dziedzinie socjologii: żadna choćby masowa imigracja żywiołu etnicznie obcego nie zmienia języka tubylczej ludności, jeżeli żywioł napływowy jest cywilizacyjnie zapóźnionym i socjalnie upośledzanym (Sowa 1950c: 5).

Zresztą duża grupa przybyszów z Galicji osiadła też po zachodniej stronie Ostrawicy (w Morawskiej Ostrawie), gdzie stosunkowo szybko zasymilowała się z żywiołem czesko- lub niemieckojęzycznym, nie wpływając na niego ani dodatnio, ani ujemnie. Kellner ubolewał nad brakiem dowodów językowych („jazykových záznamů”), dokumentujących mowę ludności miejscowej sprzed 100-150 lat ${ }^{15}$, które potwierdzałyby polski charakter tej mowy. Mając takie dowody, można by, zdaniem Kellnera, dowieść słuszności tezy o polskości tego terenu przed przybyciem Galicjan, ale przy ich braku trzeba założyć czeskość gwary miejscowej (Kellner 1949 II: 85). Sam Sowa przytoczył pięć takich dowodów w postaci tekstów literackich i propagan-

14 Wałachem nazywano na Śląsku Cieszyńskim (i nie tylko) po prostu górala pasterza, podobnie jak mieszkańca nizin nazywano lachem. Wałach więc z rumuńską Wołoszczyzną nie musiał mieć nic wspólnego (por. Małecki 1938: 21, 29).

15 O ile Kellner miał na myśli zapisy dialektologiczne, należałoby się zastanowić, czy istnieją takie dawne świadectwa z jakichkolwiek innych terenów gwarowych, skoro dialektologia jako dyscyplina naukowa zaczęła się rozwijać dopiero w drugiej połowie XIX w. 
dowych ${ }^{16}$, wspominając na marginesie o niewykorzystanej przez Kellnera gwarowej „masie toponomastycznej”.

\section{Stanowisko Karola Dejny}

Prawdopodobnie pod wpływem sugestii Sowy ówczesny redaktor naczelny „Zwrotu” skierował do K. Nitscha prośbę o naukową opinię na temat pracy Kellnera. Siedemdziesięciosześcioletni Nitsch, usprawiedliwiając się chorobą oczu, zadaniem tym obarczył o wiele młodszego, niespełna czterdziestoletniego kolegę, K. Dejnę, który opracował taką opinię i przekazał redakcji „Zwrotu” (Dejna 1953).

Na wstępie Dejna, co prawda, wysoko ocenił „bardzo szczegółowe i ilustrowane doskonale materiałem omówienie dzisiejszego stanu głosek w gwarach zachodniocieszyńskich" (ibid.: 13), pozostała część opinii jest jednak zdecydowanie krytyczna, aczkolwiek mniej kąśliwa niż artykuły Sowy. Negatywnie odnosi się Dejna do samego tytułu pracy, czyli do terminu „narzecza wschodniolaskie”, który uważa za „najbardziej osobistą sprawę autora”, a nie za fakt językowy. Zdaniem Dejny termin ten jest sprzeczny z cechami, które narzecze to wykazuje, oraz z charakterem innych gwar śląskomorawskich (laskich):

Jeżeli bowiem jeden z dialektów czeskich nazywamy dialektem laskim i równocześnie o polskich gwarach zachodniocieszyńskich mówi się jako o wschodnim odłamie tego dialektu, to fakt ten ma swoją wymowę (ibid.).

Dejna uważał, że tytuł pracy świadczy o umyślnym przywłaszczeniu sobie przez czeską dialektologię terenu językowo polskiego, i zastanawiał się nad tym, co skłoniło Kellnera do takiego posunięcia, skoro „podawany przez niego materiał tego nie uzasadnia”. Nie przekonywało go tłumaczenie się obawami przed ewentualnymi sankcjami ze strony wojennych władz protektoralnych, ponieważ obawy te musiałby budzić sam udostępniony w pracy materiał językowy, który posiadał „prawie wszystkie cechy właściwe dialektom polskim” (ibid.). W odniesieniu do gwary cieszyńskiej Dejna nie używał sformułowania „czysto polski”, tak jak czynił to Sowa, ponieważ zdawał sobie sprawę z obecności obcych elementów językowych w każdej odmianie języka, tym bardziej - w odmianie sąsiadującej z innymi językami etnicznymi. Ważne są, zdaniem Dejny, charakter zapożyczeń, częstotliwość ich sto-

16 Sowa odesłał do oryginalnego tekstu religijnego Prawdziwa Jedźina do Nieba $z$ Pisma Świentego dokazana Droga z 1761 r.; wspominał zabiegi Leopolda Szersznika o zastąpienie czeskich podręczników w szkołach cieszyńskich podręcznikami polskimi; wymieniał powieść Zaraza gorzałki (1844), która wyszła spod pióra Morawianina, pastora Jana Vinklera, w języku polskim (a nie czeskim), by jej treść była dla ludu cieszyńskiego zrozumiała; podkreślał język polski prasy cieszyńskiej w latach 1848-1849 i następnych; wskazywał też na broszurkę agitacyjną napisaną w 1848 r. po polsku i adresowaną do ludności w okolicach Polskiej (Śląskiej) Ostrawy (Sowa 1950c: 6). 
sowania oraz stopień ich zadomowienia (tu autor cytował odpowiednie przykłady). Problem polegał według Dejny na tym, że Kellner starał się udowodnić, że „gwary południowo-zachodniej części Śląska są przejściowe" (ibid.), co nie jest zgodne z prawdą, ponieważ charakter przejściowy mają dopiero sąsiednie dialekty laskie, czyli - w terminologii Kellnera - środkowo- i zachodniolaskie (středo- i západolašké). Co do niesolidności argumentacji opartej na słownictwie nie warto niczego dodawać, na obszerniejszy komentarz zasługują wspomniane zjawiska systemowe. I tu następuje rzeczowe omówienie wszystkich (18) punktów wykładu Kellnera i cierpliwe, sukcesywne obalanie tez niemających naukowego uzasadnienia, świadczących albo o braku wiedzy ich autora, albo (co wydaje się bardziej wiarygodne) o istnieniu jakichś celów nadrzędnych, którymi się kierował.

Powyższe uwagi nie mają na celu ani nie potrafią obniżyć pełnej wartości monografii prof. Kellnera i ogromnej zasługi autora, który zebrał bardzo sumiennie i opracował tak cenny materiał gwarowy [...]. W naszych rozważaniach chodziło o zwrócenie uwagi, że na podstawie tak obiektywnie przedstawionego materiału autor wyciągnął wnioski, z którymi nie zawsze można się zgodzić

- kończy swoją opinię Dejna (1953: 15)

Niedługo po ukazaniu się pracy Kellnera Východolašská nářečí (1946-1949) Dejna opublikował swoją dwuczęściową monografię (Dejna 1951-1953), opisującą tereny gwarowe między Raciborzem a Karniowem (Krnov), Opawą i Hulczynem (Hlučín). I w tym wypadku chodzi o gwary laskie występujące na terenie państwa polskiego, których użytkownicy określani są jako Morawcy ${ }^{18}$. Zadania polegającego na ustaleniu granicy między polskim i czeskim językiem etnicznym podjął się Dejna prawdopodobnie niezależnie od Kellnera, i to już w 1948 r. Jak sam podkreślał we wstępie do tomu pierwszego, badaniami został objęty wycinek terenu należącego do ówczesnych powiatów raciborskiego, rybnickiego i głubczyckiego (łączna liczba badanych wsi wynosiła 51), czyli obszarów w okolicach rzek Troi i Psiny i ich dopływów, gdzie kontaktują (kontaktowały) się gwary polskie (śląskie) z laskimi. Jak już zostało

17 Na opinię Dejny zareagował czeski językoznawca František Kopečný (1953), ceniony etymolog i dialektolog. Nie wiemy, czy śledził on dotychczasową dyskusję na temat pogranicza czesko-polskiego, czy po prostu został poproszony o zabranie w niej głosu, w każdym razie ewidentnie starał się całą sprawę załagodzić, przyznając w niektórych punktach rację Dejnie, być może dlatego, że Kellner w tym czasie już nie żył. Czynił jednak Dejnie zarzut, że używany przez niego termin gwara zachodniocieszyńska jest tak samo nieodpowiedni, ponieważ orzeka tylko o położeniu geograficznym dialektu. Kopečný zaproponował poniekąd kuriozalne rozwiązanie terminologiczne w postaci nazwy slezská nářečí zahraniční (zagraniczne - z perspektywy polskiego języka etnicznego), która na szczęście nie zadomowiła się w dialektologii.

18 Wspólnota ta, nazywana morawską za sprawą dawnej przynależności do diecezji ołomunieckiej, żyła do 1742 r. w ramach monarchii habsburskiej, od 1743 - państwa pruskiego, powiatu głubczyckiego; w powojennej Polsce uległa stopniowej asymilacji językowej i kulturowej z resztą narodu polskiego. 
zauważone, drugie $\mathrm{z}$ wymienionych gwar uważał autor zgodnie z polską tradycją dialektologiczną za przejściowe, czesko-polskie.

Tereny te były penetrowane nie po raz pierwszy. Dejna nawiązał do opracowania Feliksa Steuera (1934, 1937), do artykułu Františka Stavařa (1930), do pracy Z. Stiebera (1934), ujmującego problem gwar laskich nieco szerzej, oraz do szczegółowego rozdziału B. Havránka Nářč́ česká (1934) umieszczonego w trzecim tomie pracy Československá vlastivěda - Jazyk. Wymienił również pracę Kellnera, zaznaczając, że jego (Dejny) praca opisuje tereny gwarowe sąsiadujące od południa z innymi polskimi terenami gwarowymi, które „dokładnie i szczegółowo opracował, tylko trochę dziwnie nazwał A. Kellner" (Dejna 1951 I: 10).

Praca Dejny jest równie obszerna i szczegółowa jak Východolašská nárečí. Kwestionariusz do badań terenowych zawiera ok. 500 pytań i sprawdza wszystkie istotne cechy fonologiczne, ewentualnie morfologiczne. Dodajmy, że wiele przykładów występuje zarówno w pracy Dejny, jak i Kellnera, np.: śnieg (śńyg/śńyk, sńich, śnich, śnich, śńych), siekierka (sekyrka, śekyrka, śek'yrka, śekjyrka, śekirka, sekirka) lub ciotka (četka, ćetka, ćotka). Do wspólnie (przez Dejnę i Kellnera) omawianych zjawisk należą np.: brak mazurzenia, frykatywne $\check{r}$, dwuwargowe $\ell$, głoska $h$, obecność grup $\check{c} i$, ži, ši, forma $d v$ 'e okna, M. i B. l. mn. ty, formy (on) ńys, umřit, umřity itp. W zakończeniu tomu drugiego (1953 II) Dejna podtrzymał stanowisko Nitscha (1909: 275), iż badane gwary laskie, które występują po południowo-zachodniej stronie przywołanej powyżej linii, to gwary przejściowe, natomiast obszary po stronie północno-zachodniej (gwary cieszyńskie) należą do polskiego języka etnicznego. I na tym polega podstawowa różnica między obiema pracami ${ }^{19}$. A przesuwanie przez Kellnera granicy językowej czesko-polskiej w kierunku północno-wschodnim Dejna skomentował w ten oto sposób:

Jeśli opieramy swoje rozważania na płaszczyźnie synchronicznej, to trudno uzasadnić w sposób przekonujący, dlaczego północno-wschodnie skupienie cech laskich,

19 Wymiana zdań pomiędzy Kellnerem i Dejną nie ograniczała się jednak do komentarzy odnoszących się do pracy Východolašská nárečí. Obaj prawdopodobnie z wielką czujnością i zainteresowaniem śledzili aktywność badawczą drugiej strony i informowali o niej szerszą publiczność. W tym miejscu możemy posłużyć się takim oto przykładem: Dejna opublikował artykuł Z najnowszej dialektologii śląskiej (1949), a rok później drugi - Pogranicze językowe ślasko-morawskie (1950/2009), na co natychmiast zareagował Kellner tekstem Na okraj nových polských prací o jazykovém pohraničí polsko-českém na Hlubčicku a Ratibořicku (1951a: 243-252). Czeski językoznawca najpierw wyraził swoje stanowisko na temat gwary w miejscowościach Tłustomosty i Rudyszwałd (Polska) oraz Děhylov i Šilheřovice (ówczesna Czechosłowacja, dziś Republika Czeska), nie zgadzając się z Dejną w niektórych interpretacjach poświadczonych zjawisk językowych. Cenne uwagi (zasygnalizowane zdaniem: „A nakonec ještě jednu poznámku”) zawierają dwa ostatnie akapity artykułu. Kellner odrzucił tezę Dejny, że w Raciborskiem i Głubczyckiem przebiega granica pomiędzy językiem polskim a polsko-czeskimi, tzn. mieszanymi gwarami laskimi, twierdząc, że „svým celkovým skladem hlásí se laština zřetelně do jazykového souboru českého” (ibid.: 252). 
wspólnych z językami czeskim i słowackim, jest na tyle ważniejsze, że ma zdolność wyznaczania językowej granicy czesko-polskiej, a skupienie cech laskich wspólnych z językiem polskim na pasie gór po obu stronach Bramy Morawskiej jest mniej ważne i zdolności wyznaczania językowej granicy polsko-czeskiej nie posiada (Dejna 1953 II: 237).

\section{Koncepcja Jaroslava Běliča}

J. Běličc, autor fundamentalnej monografii o gwarach języka czeskiego (1972) i naukowiec udzielający się w organizacji badań na rzecz Czeskiego atlasu językowego (Český jazykovýatlas I-VI (Balhar, Jančák 1992; Balhar 1997-2011)), wyłożył oficjalnie swoją teorię afiliacji gwar do języka etnicznego po raz pierwszy w połowie lat 50. w pracy Sedm kapitol o češtinè. Př́spěvky k problematice národního jazyka (1955). Miała ona znamiona ówczesnego językoznawstwa marksistowskiego, a nazwisko Stalina pojawiło się $\mathrm{w}$ każdym $\mathrm{z}$ siedmiu rozdziałó $\mathrm{w}^{20}$. W rozdziale Postavení moravské slovenštiny a laštiny (ibid.: 65-86) Bělič uzasadniał przynależność narzeczy uważanych wcześniej (np. przez B. Havránka i Václava Vážnego) za słowackie do czeskiego języka narodowego (dokładnie do grupy dialektów wschodniomorawskich) tym, że kwestia systemu języka lub jego odmiany nie jest tak istotna, liczy się to, kim czuje się jej użytkownik, z którym narodem się utożsamia, ponieważ gwary były tu od dawna, a narody (narodowe organizmy państwowe) - dopiero od pewnego czasu (mniej więcej od połowy XIX w.). O przynależności do narodu decyduje nie gwara, lecz odmiana kulturalna, która jest symbolem świadomości narodowej jednostki (ibid.: 74-75). Według Běliča fakt, że pewne gwary o odmiennym systemie językowym znalazły się w granicach innej jednostki politycznej (gwary słowackie - w Republice Czeskiej byłej Czechosłowacji), jest po prostu dziedzictwem dawnych czasów „před konstituováním národư" (ibid.: 75). Argumentacja oparta na podstawach czysto językowych była - zdaniem tego badacza - wykorzystywana przez nacjonalistyczną burżuazję w celach politycznych, podczas gdy jedyne właściwe rozwiązanie przynosiła filozofia Stalina, umożliwiająca użytkownikom gwary dokonanie swobodnego wyboru. W podobny sposób wyjaśnił Bělič powstanie czesko-polskiego pogranicza językowego (ibid.: 76-86): język narodowy nie jest mechaniczną sumą odmian dialektalnych, ale zawiera też sferę postaw, stanowisk i odczuć tych, którzy się z nim identyfikują (ibid.: 85). Běličowi spodobała się szczególnie metafora Stalina o rzekomym wlewaniu się dialektów do języka ogólnonarodowego (w domyśle: urzędowego, państwowego, ogólnego/literackiego), który w danym organizmie państwowym

20 Bělič cytował dwie prace Stalina, które zostały przetłumaczone na język czeski: Marxismus a národnostní a koloniální otázka (1949) oraz O marxismu v jazykovědě (1950). Współzawodniczenie w tym, kto jest gorliwszym marksistą i kto lepiej zrozumiał słowa Stalina, przypominała też wspomniana obrona Kellnera (1951b). 
jakoby pokrywa jednym dachem wszystkie (pozostałe) odmiany i rozstrzyga o ich przynależności do danego języka etnicznego (ibid.: 18).

Jak się okazuje, od lat 50. do początku lat 70. Bělič wyraźnie nie zmienił swojego poglądu (używał nawet bardzo podobnych sformułowań), chociaż o pracach Stalina już nie wspominał. W monografii Nástin české dialektologie (Bělič 1972) badacz ten pisze: „Granice geograficzne języka kulturalnego, który dana zbiorowość uważa za swój, stanowią w czasach nowoczesnych kryterium bardziej istotne niż anachroniczne izoglosy zjawisk dialektalnych" (ibid.: 17). Inaczej mówiąc, jednostka może uważać się za członka narodu A bez względu na to, że na co dzień używa gwary języka B.

O ile w Siedmiu rozdziałach o języku czeskim Bělič (1955) stał po stronie Kellnera, twierdząc, że użyta przez niego nazwa východolašská nárečí jest w pełni uzasadniona, o tyle w publikacji z 1972 r. wyrażał się o nim zdecydowanie mniej pochlebnie, pisząc, że wnioskowania Kellnera o pierwotnej czeskości opisywanego terenu są jednostronne, chybione i sporne (Bělič 1972: 340). Sam zresztą gwarę cieszyńską określił w inny sposób, wprowadzając do czeskiej dialektologii kolejny niezbyt fortunny termin náréčí polsko-českého smišeného pruhu².

\section{Kolejna reakcja Karola Dejny}

K. Dejna zareagował na obie prace Běliča. Praca Sedm kapitol o češtině została jego zdaniem - napisana pod wpływem "fascynacji artykułami Stalina” (Dejna 1977/2009). Nazwał ją „próbą sztucznego przysłaniania problemów mniejszości narodowościowych" (ibid.: 477). Dejna nie dostrzegał w teorii Běliča żadnej naukowości (używał określenia „zupełny nonsens”), pisząc:

Przy ustalaniu językowej przynależności gwar peryferyjnych musimy opierać się na konkretnych zjawiskach językowych [które Bělič doskonale znał - I.B.], a nie na poczuciu przynależności narodowościowej, kulturalnej, państwowej itd. ludzi mówiących danym narzeczem (ibid.)

i podając analogiczne przykłady gwar czeskich w okolicach Kudowy, Głubczyc, Bełchatowa czy gwar białoruskich na Białostocczyźnie, których polska dialektologia nie nazywa polskimi.

Fakt, że do czterech czeskich zespołów dialektalnych Bělič dołączył kolejny - zachodniocieszyński, polski językoznawca uważał za decyzję „wskroś osobliwą”, „,ównie bezpodstawną" jak ta, którą Bělič zaprezentował w pracy Sedm kapitol o češtině

21 Ostatecznie w czeskiej dialektologii zadomowił się staro-nowy termin nářeči slezskopolská, którego konsekwentnie używa np. Balhar (2002: 399) w haśle encyklopedycznym dotyczącym dialektów śląskich. 
(ibid.: 478), i wyjątkowo szkodliwą, ponieważ opublikowaną w podręczniku do nauki dialektologii języka czeskiego, czyli „w pracy, która będzie szeroko propagowała błędne według nas i wymierzone przeciw interesom polonijnych ośrodków w Czechosłowacji poglądy" (ibid.) $)^{22}$.

Do uwag Běliča, ale też Kellnera i innych czeskich dialektologów Dejna wracał niejednokrotnie, także w późniejszych swoich pracach. Był wtedy o wiele bardziej krytyczny, czemu nie można się dziwić, skoro od czasów ukazania się Východolašských nářečí upłynęło prawie 30 lat. Dejna prawdopodobnie przypuszczał, że sprawa została już dostatecznie wyjaśniona i zamknięta. Okazuje się, że bezpodstawnie, a ponowne przeinaczanie prawdy odczuwał bardzo boleśnie. W tym miejscu warto przytoczyć obszerniejszy fragment jego artykułu:

Te odcięte granicą państwową gwary polskie ostatnio dwukrotnie usiłowano włączyć do terytorium czeskiego językowego, traktując je jako jeden z czeskich zespołów gwarowych. Najpierw Adolf Kellner w doskonałej zresztą pod względem materiałowym pracy nazwał gwary polskie na zachód od polsko-czeskiej granicy państwowej terminem „východolašská nářeči”. [...] Ponieważ dialekt laski uważany jest powszechnie za jedno z narzeczy czeskich, nazwanie odciętych granicą polityczną polskich gwar południowej części dialektu śląskiego „narzeczem wschodniolaskim” miało swą przykrą dla Polaków zaolziańskich [...] wymowę, zwłaszcza że użycie tu terminu tego na pewno nie było przypadkowe, skoro na zakończenie swych wywodów autor powiedział wyraźnie: „Oblast východolašských dialektů náležela od původu k jazykovému souboru československému" i została, jak sobie wykalkulował A. Kellner, spolonizowana na skutek silnego przypływu ludności polskiej w ciągu XVII-XIX wieku. [...] „A tak polskost západního Těšínska, postulovaná polskými badateli, nemá prastarých kořenů [...]" (ibid.: 471-472).

W pracy Dialekty polskie (1973) w rozdziale o dialekcie śląskim (s. 261-266) Dejna przyjął jako fakt, że do polskiego zespołu dialektalnego należy „przyległy pas polskich gwar na lewym brzegu Olzy po dorzecze Lucyny” (cz. Lučina ${ }^{23}$ ) oraz „Czadeckie w dolinie Kysucy” (Słowacja) (ibid.: 261). Równocześnie podtrzymał (za Nitschem), że najbardziej na zachód położone językowo polskie miejscowości Śląska Cieszyńskiego to: Horní Lomná, Řeka, Komorní Lhotka, Dobratice, Domaslavice, Soběšovice, Václavovice, Horní Datyně, (Ostrava): Bartovice, Radvanice, Heřmani$\mathrm{ce}^{24}$ oraz Pudlov i Bohumín, a losy tych terenów ujął w słowa:

22 Z kolei uwadze Běliča nie umknęła praca Dejny Polsko-laskie pogranicze językowe na terenie Polski (1951-1953). W monografii Nástín české dialektologie (Bělič 1972) wyraził się o niej mniej więcej w ten oto sposób: publikacja Dejny jest w pewnym sensie polskim odpowiednikiem pracy Kellnera, ponieważ podobnie jak Východolašská nářečí zajmuje się przyczyną i afiliacją językową polsko-czeskich terenów pogranicznych. W przeciwieństwie do Kellnera Dejna miał do dyspozycji o wiele bogatszy dorobek dialektologii polskiej, ale także jemu nie udało się uniknąć błędów wynikających z przemieszania faktów językowych z faktami historycznymi (ibid.: 340). Niewielka rzeczka, która wpada do Ostrawicy na terenie miasta Ostrawy. 
Po pierwszej wojnie światowej na skutek specyficznego układu sił i błędów naszej polityki ta zachodnia część zwartego obszaru języka polskiego nie została włączona do Polski, lecz pozostała i do dziś pozostaje w obrębie państwa czeskiego (Dejna 1977/2009: 471).

\section{6. Łagodzące podejście Arnošta Lamprechta}

W sprawie domniemanego późniejszego osadnictwa polskiego na Śląsku Cieszyńskim Dejna powołał się na innego czeskiego językoznawcę, A. Lamprechta, konkretnie na rozdział jego autorstwa pt. Jazyková situace na širším Ostravsku (1967) dotyczący języka na czeskim Śląsku.

Choć Lamprecht należał do grona czeskich dialektologów, podkreślał piastowskie korzenie Śląska Cieszyńskiego, na które późniejsze przyłączenie tego regionu do ziem Korony Czeskiej (luksemburskiej) nie miało zasadniczego wpływu (ibid.: 47). Konsekwentnie odróżniał dwa pojęcia: dialekty slezskomoravské (laskie) i těšinské (západotěšínské), traktując drugie jako śląskie, ale polskie. Nie starał się rozstrzygnąć kwestii „narodowości” Gołężyców, uważając ich po prostu za szczep (zachodnio)słowiański. Wpływy dialektów laskich na zachodniocieszyńskie starał się uporządkować i przybliżyć (ibid.: 65), niestety z „kellnerowskimi” usterkami, które zostały już zakwestionowane przez Sowę (1950a-c) i Dejnę (1953). Wpływu czeskiego Lamprecht dopatrywał się również w konstrukcji składniowej: jo tam być, tak by śe ći níc nestało (Lamprecht 1967: 65), co może być bohemizmem składniowym przejętym przez informatora z potocznej ogólnej odmiany języka czeskiego, użytym przypadkowo (jednorazowo). Podobną wątpliwość budzą kolejne przykłady gwary zachodniocieszyńskiej, np.: rzekome bedym čakał zamiast čakoł (ze wzdłużeniem za sylabę -lr), B. l. poj. jedne cere zamiast jednưm cere (forma na - e występuje raczej w B. zaimka $t a-t e / t u m$ ), nie przekonuje niby-karwińskie $t v, k v, s v$ itp. wymawiane bez asymilacji progresywnejes.

Warto nadmienić, że Lamprecht jest też autorem artykułu-nekrologu (1953) poświęconego Kellnerowi, gdzie o zmarłym napisał: „Ačkoli nebyl př́telem polemického tónu a snažil se vždy o věcné podání, dovedl se odhodlaně a bojovně postavit za věc [...]" (ibid.: 10o), co jest niedwuznaczną aluzją do artykułu Kellnera (1951b).

25 Wręcz przeciwnie, właśnie bezdźwięczna wymowa, czyli $t f, k f$, $s f$, jest słyszalna do dziś nawet w mowie najmłodszej generacji użytkowników języka czeskiego w Ostrawie i na innych terenach śląsko-morawskich. 


\section{Podsumowanie}

Staraliśmy się odtworzyć polemikę na temat gwary zachodniocieszyńskiej, czyli cieszyńskiej po czeskiej stronie granicy państwowej, która toczyła się na przestrzeni ok. 30 lat (1949-1977). Dyskusja, w której uczestniczyli czołowi przedstawiciele czeskiej i polskiej dialektologii, nie ograniczała się do kręgów naukowych, lecz przeniosła się również na grunt publicystyki. Na to, co dzieje się w czeskiej dialektologii i jak traktuje ona tereny językowo polskie w Czechosłowacji, zwracano uwagę ludności zaolziańskiej w prasie lokalnej. Informacje przekazywane czytelnikom nie zawsze były jednak obiektywne. Artykuły odznaczały się ekwilibrystyczną grą słów, docinkami i ironią, eksponowały rzeczy mniej istotne, modyfikowały zawarte w pracach dialektologicznych treści.

Obserwując rozwój tej polemiki oraz analizując jej cechy, dochodzimy do przekonania, że dyskutowany temat należy do wyjątkowo zawiłych i mętnych, każda ze stron bowiem dostrzega w gwarze zachodniocieszyńskiej coś innego: czeska dialektologia dopatruje się w niej elementów czeskiego języka etnicznego (żywych lub archaicznych, podstawowych lub peryferyjnych), polska ocenia ją jako rdzennie polską. Kolejnym utrudnieniem były - jak się okazuje - pozajęzykowe czynniki natury ideologicznejej ${ }^{26}$, politycznej. Okazuje się, że na tle niełatwych okresów w historii obu narodów (pierwsza połowa lat 50., początek lat 70.) uprawianie językoznawstwa wymagało oprócz odpowiedniej erudycji i doświadczenia także pewnej osobistej odwagi.

Oprócz Kellnera, Běliča i Dejny w dyskusji zabierali głos inni polscy i czescy językoznawcy - nazwiska większości z nich zostały w powyższym tekście podane. Chociaż kolejny rozwój myśli dialektologicznej zaowocował wieloma innymi pracami na interesujący nas temat (ich autorami byli/są: K.D. Kadłubiec, Edward Lotko, Władysław Milerski, Janina Labocha, Zbigniew Greń, Jana Raclavská, Irena Bogocz(ová) i inni), wydaje się, że w dyskusji na temat gwary zachodniocieszyńskiej nie postawiono jeszcze kropki nad i.

\section{Literatura}

Balhar J. (red.), 1997-2011, Český jazykový atlas II-VI, Praha.

BAlHar J., 2002, Skupina nářeční slezská, [w:] P. Karlík, M. Nekula, J. Pleskalová (red.), Encyklopedický slovník češtiny, Praha, s. 396-399.

BAlHaR J., JANČÁK P. (red.), 1992, Český jazykový atlas I, Praha.

26 Jest rzeczą znaną i zrozumiałą, że w językoznawstwie sporo jest ideologii i że językoznawstwa nie da się uprawiać zupełnie bezstronnie, co wcale nie wartościuje tej dziedziny nauki negatywnie. Zdaniem Stanisława Borawskiego (2000: 9) ,ideologia nie jest zaprzeczeniem naukowości”, takim zaprzeczeniem jest mitologia. 
BĚLIČ J., 1955, Sedm kapitol o češtině (Př́ispěvky k problematice národního jazyka), Praha.

BĚLIČ J., 1972, Nástin české dialektologie, Praha.

Bogocz I., 2016, „Jak oni mówią?”, czyli próba interpretacji języka Polaków na Zaolziu, „LingVaria” nr 2 (22), s. 227-242, [on-line:] http://dx.doi.org/10.12797.LV.11.2016.22.15.

Bogoczová I., 2015, Szkice z dialektologii języka czeskiego. 1. Stratyfikacja czeskiego języka narodowego, „Bohemistyka” XV, nr 4, s. 311-331.

Bogoczová I., 2016, Szkice z dialektologii języka czeskiego. 2. Tradycje czeskiej dialektologii od jej zarania do II wojny światowej, „Bohemistyka” XVI, nr 2, s. 133-147.

BoraWski S., 200o, Wprowadzenie do historii języka polskiego. Zagadnienia historiozoficzne, Warszawa.

Davídek V., 1940, Osídlení Těšínska Valachy, Praha.

Dejna K., 1949, Z najnowszej dialektologii śląskiej, „Język Polski” XXIX, s. 206-215.

Dejna K., 1950/2009, Pogranicze językowe ślasko-morawskie, [w:] idem, Wybór pism polonistycznych i slawistycznych, red. S. Gala, Łódź, s. 337-344.

Dejna K., 1951-1953, Polsko-laskie pogranicze językowe na terenie Polski, t. I, 1951, t. II, 1953, Łódź.

DejnA K., 1953, Gwary zachodnio-cieszyńskie w pracy czeskiego uczonego, „Zwrot” V, nr 8-9 (45-46), s. 12-15.

Dejna K., 1973, Dialekty polskie, Wrocław - Warszawa - Kraków - Gdańsk.

Dejna K., 1977/2009, Przynależność językowa gwar zachodniocieszyńskich, [w:] idem, Wybór pism polonistycznych i slawistycznych, red. S. Gala, Łódź, s. 471-498.

Havránek B., 1934, Nářečí česká, [w:] Československá vlastivěda III. Jazyk, Praha, s. 84-219.

KadŁubiec K.D., 2005, Derlich Leon, [w:] L. Dokoupil, M. Myška, J. Svoboda (red.), Kulturněhistorická encyklopedie Slezska a severovýchodní Moravy II, Ostrava, s. 187.

Karaś H., 2014, Gwary przejściowe i mieszane, [w:] Dialekty i gwary polskie. Kompendium internetowe, red. eadem, [on-line:] http://www.dialektologia.uw.edu.pl/index.php ?l1=mapa-serwisu\&l2=gwary-przejsciowe-i-mieszane-mwr (dostęp: 22 VII 2014).

Kellner A., 1946a, Slezsko po stránce jazykové, [w:] J. Macůrek (red.), Slezsko, český stát a česká kultura (cyklus přednášek pořádaný Masarykovou universitou v Brně), Opava, s. 92-113.

Kellner A., 1946b, Jazykové poměry v levém horním Poodří, [w:] B. Sobotík (red.), Naše země, náš lid. Hlubčicko, Ratibořsko, Kozelsko, Opava, s. 75-94.

Kellner A., 1946-1949, Východolašská nářečí, t. I, 1946, t. II, 1949, Brno.

Kellner A., 1951a, Na okraj nových polských prací o jazykovém pohraničí polsko-českém na Hlubčicku a Ratibořsku, „Slezský sborník” 49, s. 243-252.

Kellner A., 1951b, Aby bylo jasno, „Slezský sborník” 49, s. 548-565.

KopečnÝ F., 1953, Ještě východolašská nářeči, „Slezský sborník” 51, s. 564-565.

Laвосна J., 1997, Polsko-czeskie pogranicze na Śląsku Cieszyńskim. Zagadnienia językowe, Kraków.

LAmprecht A., 1953, Za profesorem Kellnerem, „Slovo a slovesnost” XIV, s. 97-102.

LAMPRECHT A., 1967, Jazyková situace na širším Ostravsku, [w:] A. Knop, A. Lamprecht, L. Pallas (red.), Dějiny českého jazyka ve Slezsku a na Ostravsku, Ostrava, s. 42-70.

MaŁecki M., 1938, Język polski na południe od Karpat (Spisz, Orawa, Czadeckie, wyspy językowe), Kraków.

Nitsch K., 1909, Dialekty polskie Śląska (z mapa), „Materiały i Prace Komisji Językowej Akademii Umiejętności w Krakowie” IV, s. 85-356. 
SowA A., 1950a, Dyskurs o przebrzmiałej legendzie i żywym dokumencie mowy (Rzecz o monografii dr A. Kellnera „Východolašská nářeči”), „Zwrot” II, nr 7 (8), s. 3-4.

SowA A., 1950b, Dyskurs o przebrzmiałej legendzie i żywym dokumencie mowy (Od Gołężyców do Błędowic), „Zwrot” II, nr 8 (9), s. 8-10.

SowA A., 1950c, Dyskurs o przebrzmiałej legendzie i żywym dokumencie mowy (Kolonizacja), „Zwrot” II, nr 10 (11), s. 4-6.

Stalin J.V., 1949, Marxismus a národnostní a koloniální otázka, Praha.

Stalin J.V., 1950, O marxismu v jazykovědě, Praha.

STAVǍ̌ F., 1930, K charakteristice moravskoslezských nářečí, „Věstník Matice Opavské” XXXV, nr 3, s. 14-27.

Steuer F., 1934, Dialekt sulkowski, Kraków.

Steuer F., 1937, Narzecze baborowskie, Kraków.

Stieber Z., 1934, Geneza gwar laskich, Kraków.

SzymeczeK J., 2013, Matice slezská i mniejszościowe szkolnictwo czeskie na Zaolziu w okresie międzywojennym, [w:] S. Folwarczny, L. Kosiec, B. Kubiczek (red.), Tu jesteśmy... Szkolnictwo polskie na Zaolziu w pierwszej dekadzie XXI wieku, Czeski Cieszyn, s. 33-40.

UPOMINAE SIĘ O ZAOLZIE, „Zwrot” 18 VII 2015, [on-line:] http://zwrot.cz/2015/o7/upominalsie-o-zaolzie (dostęp: 2 VII 2017).

\section{Eastern Lachian dialects vs. Western Lachian dialects or the dialectological battle for the Zaolzie region Summary}

The article is devoted to the historical discussion which arose around the affiliation of the inhabitants of the Czech-Polish border area with the Czech or the Polish nationality and language. The bone of contention was the dialect used in the Czech part of the Cieszyn/Těšn region. Although the discussion was generally conducted in academic circles, it was also picked up on by the local press (i.e., the cultural monthly "Zwrot"). It concerned not only the interests of Czech (Czechoslovak) and Polish dialectology, but also posed existential questions for the Polish minority living in this part of former Czechoslovakia. The article describes the basic theses published in the 1950s-1970s. Engaged in the discussion were, among others, Adolf Kellner (who originated the debate with the publication of Východolašská nářcči I., II., 'Eastern Lachian Dialects I., II.' in 1946 and 1949 respectively), Jaromír Bělič, Arnošt Lamprecht, and, representing predominantly the attitudes of Polish dialectology, Karol Dejna. The polemics were marked by the Marxist ideology of the time, and the overall policy of the Czechoslovak state, which intent was to justify the affiliation of certain linguistic areas to Czechoslovakia. 